\title{
Respect, trust, care and interconnectedness
}

\author{
May Thorseth, Siri Granum Carson \& Allen Alvarez
}

This open themed issue of Etikk i praksis compiles five diverse papers that overlap at key conceptual intersections around trust, care and responsibilities across national boundaries. Our globalized social environments have become more and more complex, and the information needed to understand society and our moral responsibilities have grown ever more challenging. The 'fake news' buzzword, used by various societal actors to cast doubt on political rivals, is shaking the trust needed to be confident about institutional sources of information. The caring attitude that serves to cement social groups and communities seems to be weakening in certain contexts, resulting in individual acts of unimaginable violence that shock us to the core. On the other hand, we are inspired when the same caring attitude mobilizes groups and individuals to reach across national boundaries and aid those who are suffering. In sorting through the generalizations and attempts to categorize the many highly complex social phenomena that occur in our interconnected global realities, we apply careful analysis of both facts and values that facilitate ethical reflection, helping us to make ethical decisions.

Five authors have contributed papers that represent their careful consideration of different ethical issues touching upon the broad themes of trust, care and global interconnectedness. The first article by Cornelia Vikan, Soldiers and 'respect' in complex conflicts: an Afghan case, is a timely contribution to the discussion of the ethics of war. It continues the discussion within the tradition of Just War theory and highlights the growing reality that individual soldiers now encounter situations where they need to make moral decisions on the ground, guided by the core values of their military organization. Vikan analyses the case of the Norwegian Armed Forces and its core value of 'respect'. She problematises the meaning of respect in the context of Norwegian soldiers deployed in Afghanistan, specifically those who take part in the International Security Assistance Force (ISAF). Her article highlights how the value of trust clashes with the value of respect in relation to the cooperation between Norwegian soldiers and a group of mujahedeen, especially when faced with objectionable practices of the cooperating party. Vikan's analysis leads her to conclude that soldiers should value recognizing unacceptable practices and accept the moral compromises that follow from having to choose between competing moral obligations. Soldiers should focus on maintaining an ethical standard and avoid using irrelevant concepts to justify practices that are unacceptable.

In the second article, Political control and journalist protests in Spanish public media in electoral campaigns: A decade of conflict, Carme Ferré-Pavia discusses the extended conflict concerning the so-called electoral coverage quotas in Spanish media, which regulate the coverage time for political parties in accordance with the election results. Catalan journalists view the regulations as an attack against the freedom of the press, and their protests include so-called 'signature strikes'. Ferré-Pavia reviews the conflict and its historical roots, and uses it as a point of departure from which to discuss professional roles, trust and mistrust and related 
information ethics issues. She concludes by considering the prospect of increasing the level of trust between journalists and politicians and thereby bringing the conflict to an end.

The tale of Midas' touch shows how our desire for material wealth may lead to harm. In the third article, Midas' gift means death: Tax dodging is the biggest obstacle for global justice, Hans Morten Haugen argues that tax avoidance and tax evasion constitute a major impediment for reducing socioeconomic inequalities, both within nations and on a global scale. Haugen shows how economic globalization threatens a just taxation system, particularly in the case of multinational corporations. He evaluates OECD, Norwegian, EU and US measures against tax dodging, and discusses to what extent social contract arguments may be extended and applied to the global level in an ethical approach to tax dodging.

In the fourth article, After the millennium development goals: Remarks on the ethical assessment of global poverty reduction success, Teppo Eskelinen takes a look at the progress of The Millennium Development Goals (MDGs), particularly the ethical significance of the achievements of this project not available in the official report statistics. Eskelinen also addresses some controversies and uncertainties related to MDGs and advocates for ethical analysis that keeps pace with the changing official definition of poverty. In fact, he proposes that ethical deliberation should inform new definitions in order to avoid mistakes. A more suitable analysis of poverty - in terms of human development and capabilities, for example can remedy the inadequacies of the current poverty reduction methodology.

In the last article in this special issue, $\AA$ bli til $i$ det å bli sett. Om sammenvevingen av det etiske og det estetiske $i$ Trondheims minnepark for 22. juli-ofrene, Mattias Solli undertakes a phenomenological and hermeneutical analysis of Terra Incognita - Den hvite plassen (Eng. the white park), a memorial park in Trondheim city centre created for the victims of the terrorist action that killed 77 people on July 22, 2011. Bourriard, Fichte, Hegel and Gadamer are central to the author's analysis of what it means to remember people this way, referring to both the memorial park itself and some of the poems written on marble-like concrete around the park. According to Solli, the memory park bears witness to interpersonal recognition as a kind of collective memory, which he analyses as an interweaving of ethics and aesthetics. The interweaving of ethics and aesthetics is characteristic of a public community of individuals, who share memories in a double sense: in memoriam (Gk. mnéme) and as reminiscence (Gk. anamnesis). In conclusion, the author points out that the memorial park Terra Incognita reminds us of our human resource of recognition, understood as a capacity for caring and preservation.

\section{Acknowledgments}

A special thank you to all the anonymous reviewers who helped develop this first issue of Etikk $i$ praksis for the year 2018. Their expert reading and evaluation of the submissions made this issue possible. We also thank the contributing authors for submitting to the journal and collaborating with us in making the necessary changes to their written work. 